\title{
Bastide-du-Sérou (La)
}

Les Atiels

\section{(2) OpenEdition \\ Journals}

Édition électronique

URL : http://journals.openedition.org/adlfi/10780

ISSN : 2114-0502

Éditeur

Ministère de la culture

\section{Référence électronique}

«Bastide-du-Sérou (La)», ADLFI. Archéologie de la France - Informations [En ligne], Midi-Pyrénées, mis en ligne le 01 mars 1997, consulté le 20 avril 2019. URL : http://journals.openedition.org/adlfi/10780

Ce document a été généré automatiquement le 20 avril 2019.

(c) Ministère de la Culture et de la Communication, CNRS 


\section{Bastide-du-Sérou (La)}

\section{Les Atiels}

\section{Identifiant de l'opération archéologique :}

Date de l'opération : 1990 (SD)

Inventeur(s) : Dubois Claude

1 Un sondage a été implanté sur un dépôt de scories situé dans un jardin au nord du hameau des Atiels. La découverte de fragments d'amphores catalanes du type Pascual 1 et d'amphores Dr. 20 correspond au contexte chronologique déjà avancé par J.-E. Guilbaut lors d'une première opération en 1978 , fin du $\mathrm{I}^{\mathrm{er}} \mathrm{s}$. avant J.-C. -début du $\mathrm{I}^{\mathrm{er}} \mathrm{s}$. de notre ère ( Gallia, $1981: 180$ ). Les charbons de bois analysés se rapportent pour leur grande majorité à de l'aulne, du châtaignier et du genévrier.

\section{INDEX}

Index chronologique : Haut-Empire

Index géographique : Midi-Pyrénées, Ariège, Bastide-de-Sérou

operation sondage (SD) 